\title{
KEBIJAKAN PENGELOLAAN RETRIBUSI DAERAH OLEH PEMERINTAH KOTA SEMARANG TERHADAP PENEMPATAN PEDAGANG PASAR PETERONGAN.
}

\author{
Ilham Mohammad Ikhsan, Muzayanah \\ Fakultas Hukum, Universitas Stikubank (UNISB ANK) Semarang \\ E-mail :ilhammikhsan@gmail.com, muzayanah@edu.unisbank.ac.id
}

\begin{abstract}
ABSTRAK
Kewenangan Pemerintah dalam penarikan pajak dan retribusi dari masyarakat serta renovasi tidak hanya dimiliki oleh Pemerintah Pusat saja melainkan juga menjadi kewenangan Pemerintah Kota dan Pemerintah Propinsi. Hal ini sesuai dengan asas desentralisasi dan pelaksanaan otonomi daerah berdasarkan UndangUndang Nomor 32 Tahun 2004 Tentang Pemerintahan Daerah, Undang-Undang Nomor 33 Tahun 2004 Tentang Perimbangan Keuangan Antara Pusat Dan Daerah, serta Undang-Undang Nomor 28 Tahun 2009 Tentang Pajak Daerah Dan Retribusi Daerah, Peraturan Daerah Kota Semarang Nomor 9 Tahun 2013 tetang Pengaturan Pasar Tradisional. Dalam rangka pengelolaan lingkungan pasar berupa pelayanan hukum kepada masyarakat di lingkungan pasar khususnya para pedagang, Pemerintah Kota Semarang telah mengeluarkan Peraturan Daerah Nomor 4 tahun 2004 tentang Retribusi Pasar. Penelitian ini mengangkat permasalahan yaitu: 1) Bagaimana pengelolaan retribusi daerah oleh pemerintah Kota Semarang, 2) Bagaimana kebijakan Kota Semarang terhadap renovasi Pasar Peterongan, 3) Bagaimana kebijakan Kota Semarang terhadap Pengaturan pedagang pasar Peterongan Kota Semarang setelah renovasi. Tujuan dari penulisan skripsi ini adalah 1) Untuk mengetahui dan menjelaskan pengelolaan retribusi daerah oleh Pemerintah Kota Semarang, 2) Untuk mengetahui dan menjelaskan kebijakan Kota Semarang terhadap renovasi Pasar Peterongan, 3) Untuk mengetahui dan menjelaskan pengaturan pedagang pasar Peterongan Kota Semarang setelah renovasi. Penelitian ini, adalah penelitian kualitatif dengan pendekatan yuridis normatif untuk mengetahui realisasi penerapan Peraturan Daerah Kota Semarang Nomor 4 tahun 2004 Tentang Retribusi Pasar dan Peraturan Daerah Kota Semarang Nomor 9 Tahun 2013 tetang Pengaturan Pasar Tradisional terhadap pedagang pasar. Penelitian ini di Pasar Peterongan Kota Semarang yang terletak di Jalan MT. Haryono. Hasil penelitian menunjukan bahwa Pemerintah Kota Semarang terhadap pedagang pasar sudah sesuai berdasarkan Peraturan Daerah Kota Semarang Nomor 4 tahun 2004 Tentang Retribusi Pasar dan Peraturan Daerah Kota Semarang Nomor 9 Tahun 2013 tentang Pengaturan Pasar Tradisional, Dengan beberapa hal yang masih merupakan catatan kepada pemerintah Kota Semarang untuk lebih memperhatikan keberlangsungan bagi kesejahteraan pedagang pasar tradisional, kondisi fisik dan lingkungan pasar.
\end{abstract}

Kata Kunci : Kebijakan, Pengelolaan Pasar Tradisional. 


\begin{abstract}
The authority of the Government in collecting taxes and levies from the community and renovating it is not only owned by the Central Government but also falls under the authority of the City Government and Provincial Governments. This is in accordance with the principles of decentralization and the implementation of regional autonomy based on Law Number 32 of 2004 concerning Regional Government, Law Number 33 of 2004 concerning Financial Balance Between Central and Regional Governments, and Law Number 28 of 2009 concerning Regional Taxes and Retribution Regions, Semarang City Regulation Number 9 of 2013 concerning Traditional Market Settings. In the context of managing the market environment in the form of legal services to the community in the market environment, especially traders, the Semarang City Government has issued Regional Regulation Number 4 of 2004 concerning Market Levies. This study raises the problems, namely: 1) How is the management of regional levies by the Semarang City government, 2) What is the Semarang City policy towards the renovation of the Peterongan Market, 3) What is the Semarang City policy towards the regulation of the Semarang City Peterongan market trader after renovation. The purpose of writing this thesis is 1) To know and explain the management of local levies by the Semarang City Government, 2) To find out and explain Semarang City policies towards the renovation of Peterongan Market, 3) To find out and explain the arrangements for the Peterongan market traders in Semarang City after renovation. This research is a qualitative study with a normative juridical approach to determine the realization of the implementation of Semarang City Regional Regulation Number 4 of 2004 concerning Market Levies and Semarang City Regional Regulation Number 9 of 2013 concerning Traditional Market Regulations for market traders. This research was conducted in Peterongan Market, Semarang City, located on Jalan MT. Haryono. The results showed that the Semarang City Government towards market traders was in accordance with the Semarang City Regional Regulation Number 4 of 2004 concerning Market Charges and Semarang City Regional Regulation Number 9 of 2013 concerning Traditional Market Regulations, with several things that are still a note to the Semarang City government for pay more attention to sustainability for the welfare of traditional market traders, physical conditions and market environment.
\end{abstract}

Keywords : Policy, Traditional Market Management 


\section{Pendahuluan}

Pada dasarnya setiap negara yang menganut negara hukum seperti di Indonesia memiliki politik hukum sebagai suatu landasan atau dasar bagi pembangunan hukum. Politik hukum ini harus sesuai dengan cita-cita dasar atau ideologi negara. Di Indonesia sendiri politik hukum nasionalnya selaras dengan Pancasila dan UndangUndang Dasar 1945.

Wujud pelaksanaan daripada politik hukum nasional adalah melalui kebijaksanaan hukum yang dibuat oleh Pemerintah. Kebijaksanaan hukum tersebut diimplementasikan dalam bentuk peraturan perundang-undangan maupun pelayanan hukum yang diberikan Pemerintah kepada masyarakat

Salah satu bidang yang menjadi sasaran kebijaksanaan hukum Pemerintah dalam rangka pengelolaan pasar tradisional adalah pajak dan retribusi. Dalam hal ini, Pemerintah mengeluarkan kebijaksanaan hukum berupa peraturan PerundangUndangan, maupun Peraturan Daerah yang mengatur masalah pajak dan retribusi.

Pada dasarnya tujuan penarikan pajak dan retribusi oleh Pemerintah ini bertujuan untuk mengurangi kekayaan dan menghimpun dana dari masyarakat bagi kepentingan umum. Kewenangan Pemerintah dalam penarikan pajak dan retribusi dari masyarakat tidak hanya dimiliki oleh Pemerintah pusat saja melainkan juga menjadi kewenangan Pemerintah Kota dan Pemerintah Propinsi. Hal ini sesuai dengan asas desentralisasi dan pelaksanaan otonomi daerah berdasarkan Undang-
Undang Nomor 32 tahun 2004 tentang Pemerintahan Daerah, UndangUndang Nomor 33 tahun 2004 tentang Perimbangan Keuangan antara Pusat dan Daerah, serta Undang-Undang Nomor 28 tahun 2009 tentang Pajak Daerah dan Retribusi Daerah. Dengan berlakunya Undang-Undang tersebut maka penyelenggaraan Pemerintah Daerah dilakukan dengan memberikan kewenangan yang lebih luas, nyata, dan bertanggungjawab kepada daerah. Pendapatan Asli Daerah, yang antara lain berupa Pajak daerah dan Retribusi Daerah diharapkan menjadi salah satu sumber pembiayaan penyelenggaraan pemerintahan dan pembangunan daerah serta dapat meningkatkan dan meratakan kesejahteraan masyarakat. Dengan demikian daerah mampu melaksanakan otonomi, yaitu mampu mengatur dan mengurus rumah tangganya sendiri.

Dalam rangka pengelolaan lingkungan pasar berupa pelayanan hukum kepada masyarakat di lingkungan pasar khususnya para pedagang, Pemerintah Kota Semarang telah mengeluarkan Peraturan Daerah Nomor 4 tahun 2004 tentang Retribusi Pasar. Tujuan utama dikeluarkannya Peraturan Daerah Kota Semarang Nomor 4 tahun 2004 tentang Retribusi Pasar ini pada dasarnya adalah memberikan pelayanan hukum terhadap pedagang pasar tradisional dan pedagang kaki lima yang telah membayar retribusi. Pemerintah dalam hal pengelolaan pasar berkompeten untuk mengatur pedagang pasar dan pedagang kaki lima di lingkungan pasar. Hal ini dilakukan untuk menjaga agar keberadaan pedagang pasar dan 
pedagang kaki lima di lingkungan pasar senantiasa terkontrol, mengingat pedagang pasar dan pedagang kaki lima merupakan bagian dari kehidupan ekonomi masyarakat. Oleh karena itu Pemerintah perlu memikirkan pelayanan hukum bagi mereka. Di dalam pasal 3 Peraturan Daerah Kota Semarang Nomor 4 tahun 2004 disebutkan bahwa :

(1) Obyek Retribusi adalah pelayanan dan penggunaan fasilitas yang disediakan di lingkungan pasar.

(2) Jasa pelayanan dan penggunaan fasilitas sebagaimana dimaksud ayat (1) meliputi:
a. Penyediaan lahan;
b. Penyediaan fasilitas bangunan pasar;
c. Penyediaan pengamanan;
d. Penyediaan fasilitas penerangan umum;
e. Penyediaan fasilitas umum lainnya.

(3) Jasa pelayanan sebagaimana dimaksud ayat (1) meliputi :

a. Penataan / penempatan ;

b. Penertiban;

c. Pengamanan ;

d. Pengawasan.

Berdasarkan ketentuan tersebut dapat diketahui bahwa kontra prestasi timbal balik yang diberikan Pemerintah Kota Semarang kepada pedagang pasar dan pedagang kaki lima adalah penyediaan fasilitas lingkungan pasar sesuai dengan Peraturan Daerah Nomor 4 tahun 2004 tentang Retribusi Pasar.

Selanjutnya dalam ketentuan pasal 4 Peraturan Daerah Kota Semarang Nomor 4 tahun 2004 disebutkan "Subyek Retribusi adalah orang pribadi atau badan yang menggunakan atau menikmati jasa pelayanan dan penggunaan fasilitas di dalam lingkungan pasar."

Dari ketentuan tersebut diatas dapat diketahui bahwa pedagang pasar merupakan subyek retribusi yang dapat dikenakan retribusi dengan menerima jasa pelayanan dan fasilitas di dalam lingkungan pasar.

Berdasarkan latar belakang tersebut, penulis tertarik untuk mengadakan suatu penelitian dengan mengambil judul : Kebijakan Pengelolaan Retribusi Daerah oleh Pemerintah Kota Semarang terhadap Penempatan Pedagang Pasar Peterongan

\section{Metode Penelitian}

Penelitian tentang "Kebijakan Pengelolaan Retribusi Daerah Oleh Pemerintah Kota Semarang Terhadap Penempatan Pedagang Pasar Peterongan" ini merupakan suatu penelitian hukum dengan menggunakan cara pendekatan yuridis normatif yaitu merupakan suatu penelitian yang menekankan pada ilmu hukum serta menelaah kaidah-kaidah hukum yang berlaku.

Spesifikasi penelitian ini adalah ddeskriptif analitis, karena hasil penelitian ini menggambarkan peraturan perundang-undangan yang berlaku yang dikaitkan dengan analisa dengan teori-teori hukum dan suatu keadaan objek yang menjadi masalah.

Data yang dikumpulkan adalah data yang berhubungan dengan peraturan perundang-undangan yang berlaku yakni Peraturan Daerah Kota 
Semarang nomor 4 tahun 2004 tentang retribusi pasar serta pengumpulan data dalam penelitian ini mengguakan studi pustaka dan wawancara.

\section{Pembahasan}

\section{Pengelolaan Retribusi Pasar Peterongan oleh Pemerintah Kota Semarang}

Salah satu bentuk retribusi yang menjadi tanggung jawab Pemerintah Kota Semarang saat ini baik mengenai pengaturan, pengelolaan, maupun pemungutannya adalah retribusi pasar. Penarikan maupun pengaturan retribusi terhadap pedagang pasar di lingkungan pasar diatur dalam Peraturan Daerah Kota Semarang Nomor 4 Tahun 2004 Tentang Retribusi Pasar. Untuk itu penulis melakukan penelitian di Pasar Peterongan Semarang dan memberikan data di lapangan sehubungan dengan pelayanan Pemerintah Kota Semarang dalam mewujudkan kaidah hukum Peraturan Daerah Kota Semarang Nomor 4 Tahun 2004 Tentang Retribusi Pasar.

Mengenai besarnya tarif retribusi, Pasal 4 ayat (1) Peraturan Walikota Semarang Nomor 25 Tahun 2015 Tentang Perubahan Tarif Retribusi Pasar telah ditetapkan struktur dan besarnya tarif retribusi pasar. Struktur dan besarnya tarif retribusi jasa pelayanan ditetapkan sesuai dengan perbedaan golongan pasar atau perbedaan antara kios, los, dan dasaran terbuka.
Berdasarkan Peraturan Walikota Semarang Nomor 25 Tahun 2015 Tentang Perubahan Tarif Retribusi Pasar dapat diketahui bahwa penarikan retribusi pasar oleh petugas pemungut retribusi kepada para pedagang pasar di lingkungan pasar dilakukan berdasarkan golongan pasar dan golongan tempat usahanya. Dikaitkan dengan hasil penelitian di Pasar Peterongan Semarang penetapan tarif retribusi sudah sesuai dengan Pasal 4 ayat (1) Peraturan Walikota Semarang Nomor 25 Tahun 2015 Tentang Perubahan Tarif Retribusi Pasar.

Dalam pengelolaan retribusi pasar peterongan, pemerintah Kota Semarang mengeluarkan kebijakan Peraturan Daerah Kota Semarang Nomor 4 Tahun 2004 Tentang Retribusi Pasar. Tujuan dikeluarkannya Peraturan Daerah Kota Semarang Nomor 4 Tahun 2004 tentang Retribusi Pasar ini pada dasarnya adalah memberikan pelayanan kepada masyarakat, khususnya kepada para pedagang pasar yang telah membayar retribusi. Pemerintah Kota Semarang selain memberikan fasilitas juga berkompeten untuk mengatur pedagang pasar di lingkungan pasar. Hal tersebut dilakukan untuk menjaga agar pedagang pasar di lingkungan pasar dapat senantiasa terkontrol, mengingat pedagang pasar merupakan salah satu bagian dari kehidupan ekonomi masyarakat. 
Mengingat dari hasil penelitian retribusi kepada pedagang yang dihimpun dari Dinas Pasar akan di setorkan kepada Pemerintah Kota Semarang yang nantinya untuk menjadi anggaran bagi renovasi pasar Peterongan. Jadi retribusi ini merupakan dana yang dimasukan dalam APBD Kota Semarang, dengan APBD ini Pemerintah Kota Semarang akan menggunakannya sebagai renovasi pasar Peterongan. Renovasi pasar Peterongan di prioritaskan karena telah banyak terjadi kerusakan di pasar tersebut. Diharapkan dengan pungutan retribusi ini menjadi sumber biaya untuk APBD Kota Semarang sebagai salah satu sumber biaya APBD Kota Semarang.

2. Kebijakan Pemerintah Kota Semarang terhadap Renovasi Pasar Peterongan

Berdasarkan hasil penelitian penulis yang dilakukan dengan metode wawancara, bapak Setyo Utomo selaku kepala Dinas Pasar Peterongan mengatakan bahwa, "Pasar Peterongan sebelum direnovasi belum tertata dengan rapi, para penjual masih banyak berjualan di sekitar pintu masuk pasar sehingga menghambat akses transportasi masyarakat yang akan masuk ke area pasar. Jumlah kios yang ada juga belum memadai dengan jumlah pedagang yang ada sehingga banyak pedagang yang membuka lapak dadakan di pintu masuk pasar dan membuka dagangan di tempat yang seadanya sehingga mengganggu arus masuk maupun keluar pembeli. Kondisi tempat parkir juga belum memadai. Tempat parkir belum ada tempat khusus tersendiri dan dikelola dengan baik, masih banyak pedagang yang memarkirkan kendaraannya secara sembarangan untuk aktivitas bongkar muat kendaraan sehingga dapat mengganggu aktivitas para pedagang dan pembeli yang akan masuk ke dalam pasar. Para pembeli yang datang ke pasar peterongan pun dikarenakan tempat parkir yang disediakan terbatas terkadang memarkirkan kendaraan di bahu jalan sehingga sangat mengganggu dan membuat kemacetan. Kondisi lainnya yang ada adalah terbatasnya sarana dan prasarana seperti toilet umum, sehingga apabila pedagang dan pembeli akan ke toilet harus antri terlebih dahulu, itupun kondisi dari toilet tidak dikelola dengan baik."

Melihat kondisi yang ada pada pasar Peterongan sebelum renovasi, maka pemerintah melakukan kebijakan penataan pasar Peterongan. Penataan tersebut dapat dilaksanakan dengan melakukan perbaikan pada sarana fisik atau renovasi pasar peterongan. Hal tersebut perlu dilakukan perencanaan renovasi pasar peterongan terlebih dahulu.

Peran retribusi dalam pembangunan suatu kawasan, dimana retribusi yang di bayarkan oleh masyarakat akan kembali ke masyarakat dalam bentuk suatu 
pelayanan kawasan, dimana pelayan tersebut dapat di akses oleh seluruh masyarakat. Selain itu, masyarakat dapat mengontrol bagaimana pengelolaan retribusi untuk keperluan pembangunan sarana prasarana yang ada di tempat umum. Sama halnya dengan pasar Petrongan, pemerintah daerah kota Semarang tentunya mengolah atau mengelola dana retribusi untuk pembangunan sarana dan prasarana yang ada di pasar Peterongan. Dengan begitu baik pedagang maupun pembeli dapat merasakan sarana dan prasarana yang ada di pasar Peterongan yang salah satu sumber anggaran renovasinya berasal dari retribusi.

Sejauh ini pemerintah sebagai perencana program telah berhasil melakukan sosialisasi terhadap pedagang di Pasar Peterongan sehingga pembangunan pasar peterongan dapat berjalan hingga pembangunan mencapai tahap pembangunan fasilitas penunjang seperti tangga untuk menguhubungkan antara lantai 1 , lantai 2 dan lantai 3.

Berdasarkan hasil penelitian mengenai kebijakan pemerintah Kota Semarang terhadap Renovasi Pasar Peterongan telah sesuai dengan yang sudah terencana dan telah sesuai dengan Peraturan Daerah Kota Semarang Nomor 9 Tahun 2013 Tentang Pengaturan Pasar Tradisional.

Melihat dari keberhasilan program yang telah berjalan, diharapkan bisa terus berjalan hingga selesai pembangunannya sehingga hasilnya dapat dirasakan oleh semua kalangan, mulai dari pemerintah yang memiliki pasar tradisional yang modern, bersih, aman dan nyaman. Disisi pedagang juga diharapkan senang dengan kios baru yang didapatkan sehingga dapat menambah pelanggan dan menambah pemasukan, dan dari sisi pembeli dan masyarakat memberikan rasa nyaman dalam berbelanja sehingga tidak perlu lagi berbelanja di supermaket dan kembali berbelanja dipasar tradisional. Dari semua penelitian yang didapatkan hasil bahwa pemerintah merencanakan suatu program dengan maksud ingin memperbaiki citra kota Semarang yang identik dengan pasar yang kotor, bau dan tidak nyaman menjadi pasar tradisional semi modern yang aman, nyaman, bersih sehingga dapat menarik minat wisatawan domestik bahkan mancanegara agar datang ke pasar tradisional kota Semarang.

3. Kebijakan Pemerintah Kota Semarang terhadap Pengaturan Pedagang setelah Renovasi

Dari data yang diperoleh penulis, jumlah pedagang di pasar Peterongan sebelum renovasi berjumlah 1.543 pedagang

Diketahui bahwa jumlah pedagang pasar sebelum direnovasi tidak sesuai dengan jumlah lahan yang tersedia di Pasar Peterongan, yakni jumlah pedagang sebanyak 1.543 sedangkan jumlah lahanya 1.521 
yang meliputi jumlah los sebanyak 13, jumlah kios sebanyak 881, jumlah dasaran terbuka sebanyak 65 , dan jumlah pancaan sebanyak 562.

Bapak Setyo Utomo selaku kepala Dinas Pasar Peterongan mengatakan bahwa, "untuk renovasi lahan bangunan di pasar peterongan itu sendiri belum sepenuhnya terlaksana dengan baik, hanya beberapa blok saja yang sudah direnovasi dan itu hanya meliputi kios dan los." Hal ini yang menyebabkan masih adanya pedagang pasar yang berjualan di pinggir-pinggir pasar atau dengan sembarang membuka lapak.

Dari hasil peneliti diketahui bahwa jumlah pedagang di pasar peterongan sama yaitu berjumlah 1.543, tetapi untuk penempatan lahan hanya pedagang yang memiliki SIPTD / ID Card saja yang boleh memenpati los atau kios yang sudah direnovasi. Dan dari data tersebut hanya 339 pedagang yang memiliki SIPTD. Selisih pedagang setelah di renovasi adalah 362 untuk pedagang yang tidak memiliki SIPTD tidak memiliki lahan berjualan di Pasar Peterongan, sehingga pedagang yang tidak memiliki SIPTD hanya bisa berjualan di dasaran terbuka dan pancaan, tetapi tetap membayar retribusi.

Berdasarkan hasil penelitian mengenai kebijakan pemerintah kota Semarang terhadap pengaturan pedagang setelah renovasi, banyak pedagang yang belum mendapatkan lahan berjualan dikarenakan tidak memiliki SIPTD (Surat Ijin Pemakaian Tempat Dagang).

Pedagang pasar Peterongan yang tidak memiliki ID Card / SITPD masih dapat berjualan di pasar Peterongan tetapi tidak memiliki lahan tetap berupa los atau kios yang telah direnovasi, dikarenakan renovasi belum sepenuhnya terlaksana. Kebijakan pemerintah selanjutnya bagi pedagang yang belum memiliki ID Card atau SITPD akan segera terlaksana, sehingga seluruh pedagang akan segera mendapatkan lahan berupa los ataupun kios. Dalam hal ini kebijakan Pemerinta belum terealisasikan sepenuhnya.

Pedagang telah di tempatkan pada bangunan yang telah disediakan hasil dari renovasi, dengan catatan pedagang harus punya ID Card/SIPTD, namun dari kenyataan yang ada pedagang pasar banyak yang belum tertampung setelah renovasi karena bangunan yang di renovasi tidak sebanyak pedagang yang ada. Berarti sebagian ada yang sudah mendapatkan tempat dan sebagian belum mendapatkan tempat. Catatan Pemerintah Kota Semarang adalah untuk menyelesaikan pembangunan renovasi agar pedagang yang belum mendapatkan tempat masih dalam taraf untuk di berikan kesempatan untuk renovasi selanjutnya. 


\section{Simpulan}

Mengingat dari hasil penelitian tentang retribusi yang dipungut dari pedagang yang dihimpun dari Dinas Pasar akan di setorkan kepada Pemerintah Kota Semarang yang nantinya untuk menjadi anggaran bagi renovasi pasar Peterongan. Jadi retribusi ini merupakan dana Pendapatan Asli Daerah (PAD) yang dimasukan dalam APBD Kota Semarang, dengan APBD ini Pemerintah Kota Semarang akan menggunakannya sebagai renovasi pasar Peterongan. Renovasi pasar Peterongan di prioritaskan karena telah banyak terjadi kerusakan di pasar tersebut. Diharapkan dengan pungutan retribusi ini menjadi salah satu sumber biaya untuk APBD Kota Semarang.

Pemerintah melakukan kebijakan renovasi Pasar Peterongsan dengan perencanaan tata ruang, penataan dagangan, bangunan pasar, pengaturan lalu lintas, pencegahan kebakaran, kebersihan pasar Peterongan. Fasilitas yang di bangun untuk Pasar Peterongan di maksudkan agar pasar Peterongan menjadi lebih baik, tertata dan nyaman sebagai pasar tradisional yang di miliki oleh Pemerintah Kota Semarang. Diharapkan dengan adanya perencanaan renovasi tersebut Pemerintah dapat menyelamatkan fungsi dan cagar budaya pasar Peterongan.

Setelah renovasi dilaksanakan oleh Pemerintah Kota Semarang pedagang telah di tempatkan pada bangunan yang telah di sediakan hasil dari renovasi, dengan catatan pedagang harus memiliki ID Card/SIPTD, namun dari kenyataan yang ada pedagang pasar banyak yang belum tertampung setelah renovasi karena bangunan yang sudah di renovasi tidak sebanyak pedagang yang ada. Berarti sebagian pedagang ada yang sudah mendapatkan tempat dan sebagian belum mendapatkan tempat. Karena renovasi dilaksanakan secara bertahap maka tahapan renovasi berikutnya adalah untuk menempatkan pedagang yang belum mendapatkan tempat. Selanjutnya catatan untuk Pemerintah Kota Semarang adalah segera menyelesaikan pembangunan renovasi yang berlanjut, agar pedagang yang belum mendapatkan lokasi diberikan kesempatan untuk mendapat lokasi atau tempat yang telah di renovasi.

\section{Saran}

1. Saran Untuk Pemerintah Kota Semarang

Pemerintah perlu memikirkan renovasi bangunan pasar yang merata dan jika perlu menambah gedung sebagai sarana fasilitas bagi para pedagang di Pasar Peterongan Semarang yang setiap tahun bertambah. Mengingat bahwa pelayanan dalam penyediaan fasilitas umum di lingkungan pasar merupakan salah satu bentuk kewajiban Pemerintah, maka Pemerintah perlu lebih responsif terhadap kondisi fisik dan lingkungan pasar terutama yang menyangkut masalah kelangsungan kegiatan ekonomi pedagang pasar di lingkungan pasar. Selain itu diharapkan pemerintah juga dapat segera mendata seluruh pedagang pasar agar mendapatkan ID Card 
atau SIPTD, sehingga seluruh pedagang pasar bisa mendapatkan dasaran lahan di Pasar.

2. Untuk Masyarakat

Masyarakat

pedagang pasar seharusnya

memiliki kesadaran dalam menjaga lingkungan pasar sebagai fasilitas yang disediakan oleh Pemerintah.

\section{Daftar Pustaka}

\section{Literatur}

Ahmad, Mas Santoso. 2001. Good Goovernance dan Hukum Lingkungan, ICEL, Jakarta.

Ashsofa, B. 2007. Metode Penelitian Hukum, Rineka Cipta, Jakarta

Islamy, M Irfan. 1984. Prinsip-prinsip Perumusan Kebijaksanaan Negara, Bumi Aksara, Jakarta.

Manan, B. 2002, Menyongsong Fajar Otonomi Daerah, Pusat Studi Hukum (PSH) Fakultas Hukum UI, Yogyakarta.

Moleong, L. 2007. Metodologi Penelitian Kualitatif, Remaja Rosda Karya, Bandung.

Muchsin dan Fadillah Putra. 2002. Hukum dan Kebijaksanaan Publik, Averroes Press, Jakarta.

Sidobalok, Hotmauli. 1999. Politik hukum Pengenaan Pajak Bumi dan Bangunan di Indonesia, Tesis Magister Ilmu Hukum Universitas Indonesia, Jakarta.

Soekanto, S. 2005. Pengantar Penelitian Hukum, Sinar Grafika, Jakarta.

Soemitro, Rochmat. 1992. Asas dan Dasar Perpajakan, PT. Eresco, Bandung.
Soetami, Siti. 2000. Hukum Administrasi Negara, BP Universitas Diponegoro, Semarang.

Sutrisno, Hadi. 2004. Dasar dan Teknik Penelitian Research Pengantar, Yogyakarta.

Wahab, Solichin Abdul. 1991. Analisis Kebijakan dan Formulasi ke Implementasi, Bumi Aksara, Jakarta.

\section{Peraturan Perundang-Undangan}

Undang-Undang Dasar 1945

Undang-undang Nomor 18 Tahun 1997 tentang Pajak Daerah dan Retribusi Daerah

Peraturan Daerah Kota Semarang Nomor 4 Tahun 2004 tentang Retribusi Pasar

Peraturan Pemerintah Nomor 66 Tahun 2001 tentang Retribusi Daerah

Peraturan Daerah Kotamadya Daerah Tingkat II Semarang Nomor 10 Tahun 2000 tentang Peraturan Pasar

Peraturan Daerah Kota Semarang Nomor 9 Tahun 2013 tentang Pengaturan Pasar Tradisional. 